$<$ 原 著 $>$

急性肝不全患者における特殊組成アミノ酸製剤投与による

肝性脳症増悪の危険性

$\begin{array}{lllll}\text { 井上 } & \text { 和明 } & \text { 与芝 } & \text { 真 } & \text { 関山 和彦 } \\ \text { 黄 一宇 } & \text { 藤田 } & \text { 力也 } & & \end{array}$

要 旨：肝性脳症用特殊組成アミノ酸輸液 (Fischer 液) が劇症肝炎の予後を悪化させると報告 されている. 今回同液が urea cycle 機能の障害の強い急性重症肝障害例の臨床症状と $\mathrm{N}$ 処理 能に与える影響を知る目的で, 劇症肝炎 3 例, 急性肝炎重症型 1 例に Fischer 液 $500 \mathrm{~m} l$ を 2 時

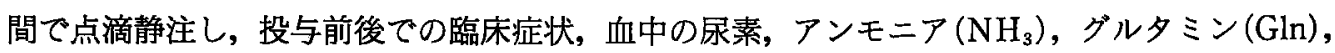
アラニン (Ala)の各值の推移を検討した。一旦肝性脳症から完全に覚醒した劇症肝炎重急性型 の 1 例で投与後昏睡 0 度からIV度に悪化し，1 例はIV度のまま不変, 回復期の 2 例は 0 度だが number connection test が悪化した. 全例で投与直後に血中 $\mathrm{NH}_{3}, \mathrm{Gln}, \mathrm{Ala}$ の異常高值が認 められ，尿素生成の不良な 2 例では高値が持続した. urea cycle 機能の高度に障害された急性 重症肝障害例では他の $\mathrm{N}$ 処理系を含めた $\mathrm{N}$ 処理能を上回った量のアミノ酸輸液を行った場 合, Fischer 液の形でも $\mathrm{NH}_{3}$ を増加させ，脳症を悪化させる危険がある.

索引用語：急性肝不全 分枝鎖アミノ酸 肝性脑症 Fischer 液

\section{緒 言}

肝不全患者では血墏アミノグラムのインバランスが 起こり，分枝鎖アミノ酸 (branched chain amino acids $\mathrm{BCAA}$ )/芳香族 $ア ミ ノ$ 酸 (aromatic amino acids AAA) 比が低下する. Fischer は，この両者が bloodbrain-barrier (BBB) を通過する際に競合するため, AAA の相対的增加により AAA が脳内に過剩に取り 込まれ, AAA から octopamineや tyramineなどの false neurotransmitter が産生されて肝性脳症が発生 するという仮説を提唱した ${ }^{1,2)}$.この仮説に基づき， BCAAに富んだ特殊組成アミノ酸輸液（Fischer 液） が, 肝性脳症改善薬として本邦て広く臨床的に使用さ れており，その投与により血整アミノ酸インバランス が是正され，脳内モノアミン代謝が正常化して, 肝性 脳症が改善することが想定されている。しかし，今日 まで行われた case-control studyに拈いて，肝硬変例 における肝性昏睡については，一定の覚醒効果が認め られているものの, 対照薬のラクッロースやグルコー スに比へて差が無いという報告や，予後については全
く改善しないとの報告もあり，今なお評価が一定しな $w^{3-6)}$.

急性肝不全においても当初有効性が主張された が7), 1982年から 7 年間本邦において高橋らによって 行われた全国集計により，急性肝不全においては特殊 組成アミノ酸投与群は非投与群に比して有意に生存率 が低下すると報告されている アミノ酸液が脳症を悪化させる可能性を示唆してい る.我々は近年開発した血槳交換 (plasma exchange, PE) と血液滤過透析 (hemodiafiltration, HDF) を組 み合わせた肝補助")によって意識を覚醒させた劇症肝 炎亜急性型の重症例において，特殊組成アミノ酸製剤 の投与によって血中アンモニア值の著增に伴い意識清 明の状態から脳症IV度まで増悪した例を経験し，既に 報告した ${ }^{103}$. 今回は尿素サイクル機能の低下の想定し うる劇症肝炎 3 例と急性肝炎重症型（PT $<40 \%$, 昏睡 0 度） 1 例において，特殊組成アミノ酸製剤の投与を 行い, 血中アンモニア值と肝蔵, 脳, 骨格筋において アンモニアの代謝に関与するとされる尿素, グルタミ

Kazuaki Inoue, Makoto YoshiBa, Kazuhiko SEKIYAMA, Ichiu KoH and Rikiya FuJITA*

"昭和大学藤が丘病院消化器内科

<受付日1995年 1 月25日 $>$ 


$$
6: 402
$$

肝

臟

ン,アラニント1)の值に与える影響を検討した.

\section{対象と方法}

対象は劇症肝炎 3 例（急性型 1 例，亜急性型 2 例） と急性肝炎重症型 1 例で, 原因ウイルスは B 型が 2 例 と NANBNC 型が 2 例である(Table). 急性肝炎重症 型の 1 例は特殊治療を必要とせず自然回復した。症例 1 から 4 のプロトロンビン時間の最低值は $9 . \dot{9} \%$, $13.1 \%, 25.8 \%, 33.3 \%$ であり, 症例 1 から 3 の最高 昏睡度はIV度, IV度, II 度であった。特殊治療は劇症 肝炎 3 例ではインターフェロンによる抗ウイルス療法 とソルメドロールのパルス療法とサイクロスポリン持 続点滴を免疫抑制潦法として行い,さらに亜急性型の 2 例は血漿交換と血液濾過透析を組み合わせた肝補助 を行った。この治療法の詳細はすでに報告している ${ }^{12}$. これらの症例に, 入院 1 週間以内の急性期に, 特殊組 成アミノ酸輸没（アミノレバン，大塚製薬） $500 \mathrm{~m} l$ を 早朝 6 時より 2 時間かけて点滴静注した。点滴開始時 より臨床症状の変化を観察するとともに, 点滴静注前, 2 時間後, 4 時間後, 肝補助療法を施行していないも のは 6 時間後に, 肝補助療法を施行しているものは 症
36巻 7 号 (1995)

例 1 と 2）24時間後にも採血を行ってアンモニア値の 経時的測定を行い，同時に血漿中のアミノ酸の分析を 行って, BCAA 值と BCAA/AAA 比抽よびアンモニ ア代謝に関与すると考えられる尿素, グルタミン,ア ラニンを経時的に検討した。アンモニア測定は全血を 用いて微量拡散法 ${ }^{13)}$ (アミチェック, 京都第一科学)に て行った.

これらの対象症例は前日の午後 8 時より絶食とし, Fischer 液投与開始の午前 6 時から正午までの間も絶 食を続けた．また前日の夜まで全例ラクツロースとカ ナマイシンの投与を行った。便秘した症例は無かった.

アミノ酸分析は autoanalyzer (JLC-300V, Nihon Denshi, Tokyo, Japan) にて行った. 可能な症例に 対しては特殊組成アミノ酸輸液の投与前後で number connection test (NCT) を施行した.

$$
\text { 成 績 }
$$

1）特殊組成アミノ酸投与前後における BCAAの 絶対值と BCAA/AAA 比の変動

BCAA は全例でアミノレバン投与終了時に血中濃 度のピークが見られたが, 終了 2 時間後にはピーク值

Table Major profiles of patients enrolled in the present study.

\begin{tabular}{c|c|c|c|c|c}
\hline case & age/sex & causal virus & diagnosis & $\begin{array}{c}\text { lowest PT values } \\
\text { (\% of normal) }\end{array}$ & $\begin{array}{c}\text { maximum } \\
\text { coma grade }\end{array}$ \\
\hline 1 & $23 / \mathrm{F}$ & NANBNC & subacute FH & 9.9 & IV \\
2 & $14 / \mathrm{F}$ & NANBNC & subacute FH & 13.1 & IV \\
3 & $45 / \mathrm{F}$ & $\mathrm{B}$ & acute FH & 25.8 & II \\
4 & $30 / \mathrm{F}$ & $\mathrm{B}$ & severe acute hepatitis & 33.3 & 0 \\
\hline
\end{tabular}

FH : fulminant hepatitis

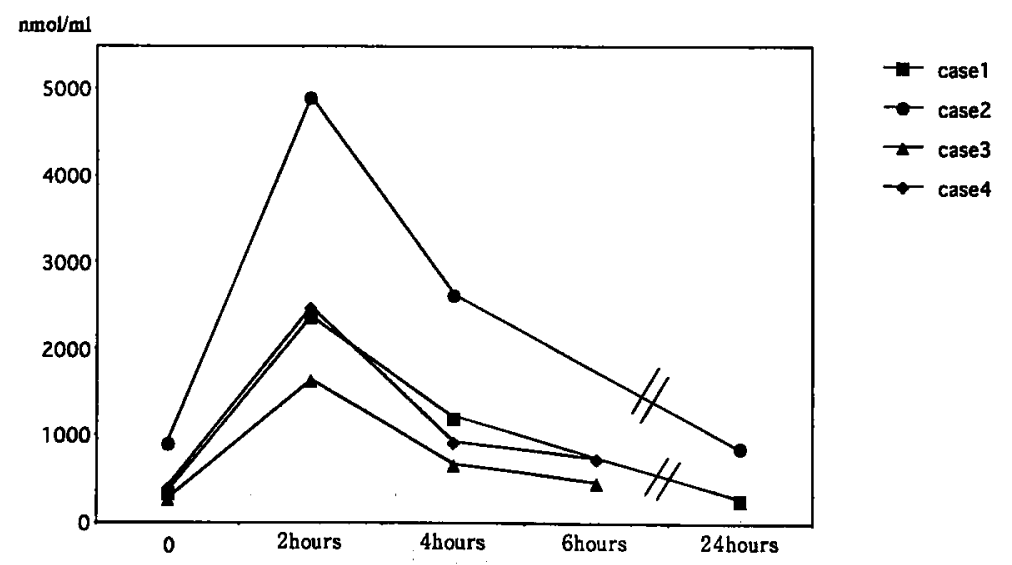

Fig. 1 Changes in plasma BCAA levels before and after the administration of Fischer's solution. 
の約 $1 / 2$ から1/3まで低下した (Fig. 1). BCAA/AAA 比は投与終了時に 4 例平均して前值 $の 6.35$ 倍 （5.0〜7.44倍）に上昇した（Fig. 2).

2）特殊組成アミノ酸投与前後における臨床症状と number connection test $\sigma$ 変化

症例 1 では肝補助により肝性昏睡 II 度から完全覚醒 し，投与前に意識清明であったが，投与終了時には肝 性脳症II度となり 6 時間後には肝性脳症IV度まで増悪 した，そのため HDF の置換液量を $12 \mathrm{~L}$ から $24 \mathrm{~L}$ に增 量して 3 日間施行することにより，脳症II度まで意識

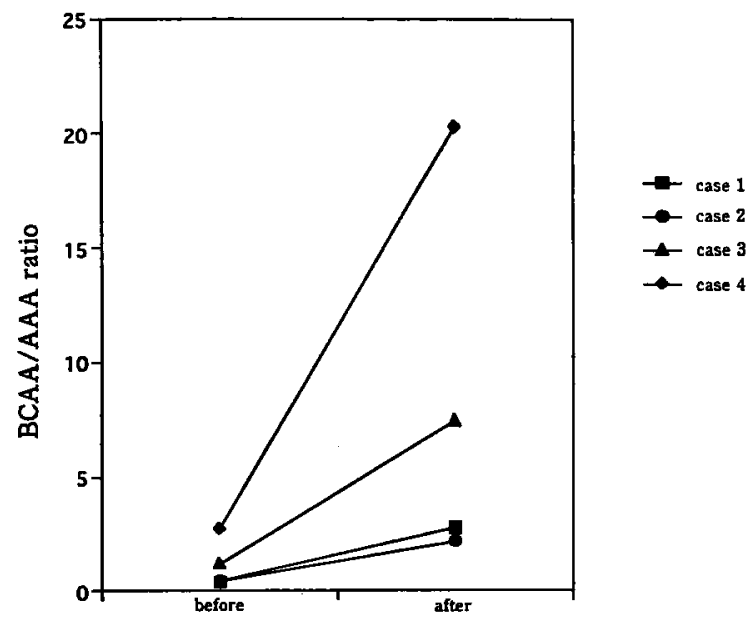

Fig. 2 Changes in BCAA/AAA ratio before and immediately after the administration of Fischer' s solution.
レベルの回復を見た. NCT は, 投与前は38秒であった が，投与終了時には施行不能となった.

症例 2 では意識レベルは肝性脳症IV度のまま不変で あった，症例 3 は治療により肝不全を脱した直後の劇 症肝炎例だが，アミノレバン投与開始 30 分後より嘔気 がみられ 6 時間持続した. NCT は投与前28秒, 投与終 了直後は62秒と延長した。症例 4 は急性肝炎重症型の 症例だが，投与 1 時間後より四気と嘔吐がみられ 4 時 間持続した. NCT は投与前が26秒であったが, 投与後 には44秒に延長した。

3）特殊組成アミノ酸投与前後での血中アンモニア 值の变動

特殊組成アミノ酸製剤投与後全例で血清アンモニア 值の上昇が見られた。特に症例 1 と症例 2 ではアンモ ニア值は投与前値の 2 倍以上に上昇し, 更に 24 時間以 上高値が持続した.

症例 3 ではアンモニア值のピークが 2 時間後に認め られたが，4時間後には正常值に回復した。症例 $4 て ゙$ はアンモニア值のピークが 2 時間後に認められたが, 6 時間後には正常值に回復した（Fig. 3).

4）特殊組成アミノ酸投与前後での尿素, グルタミ ン, アラニン値の変動

血漿の尿素值を投与前值と投与終了 2 時間後の間で 比較すると, 症例 1 から 4 でそれぞれ $400 \mathrm{nmol} / l, 220$ $\mathrm{nmol} / l, 1,516 \mathrm{nmol} / l, 1,796 \mathrm{nmol} / l$ 増加し, 症例 1 , 2 は 3,4 に比して增加量が小さかった.グルタミン とアラニンの経時変化についてはグルタミンとアラニ

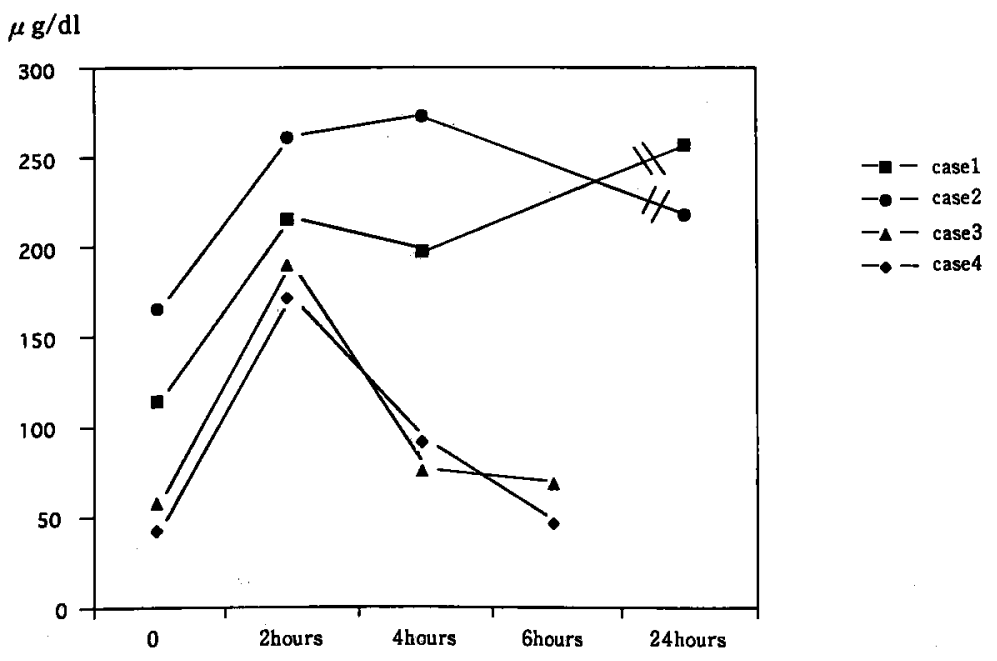

Fig. 3 Changes in blood ammonia levels before and after the administration of Fischer's solution. 


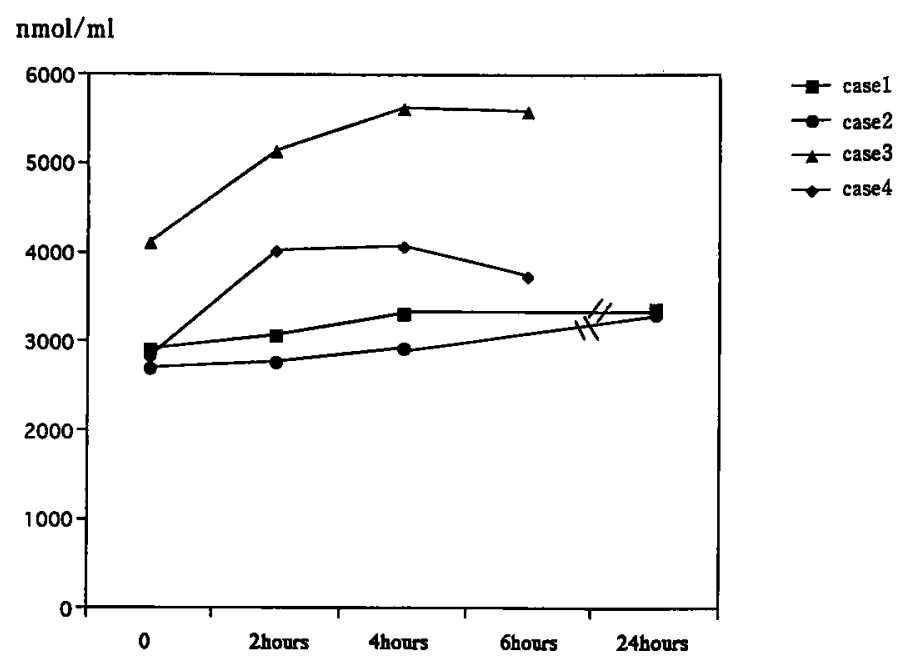

Fig. 4 Changes in plasma urea levels before and after the administration of Fischer's solution.

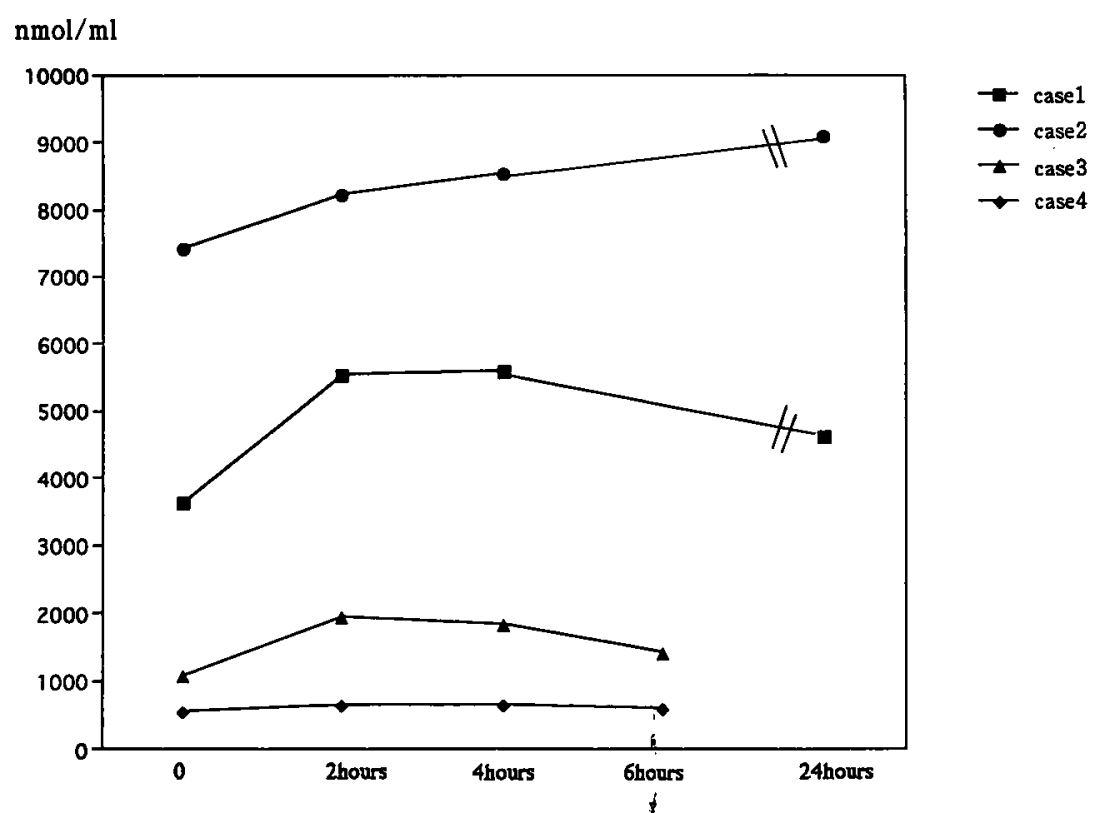

Fig. 5 Changes in plasma glutamine levels before and after the administration of Fischer's solution.

ンともに点滴終了後は全症例で血中濃度が上昇する が, 症例 3 と 4 では, 血中濃度が時間経過と共に低下 傾向をとるのに対して, 症例 1 と 2 では血中濃度が高 値のまま24時間持続遷延した (Fig. 4, 5, 6).

\section{考案}

今回の検討では特殊組成アミノ酸輸液の投与により 全例で血中アンモニア值の異常値への上昇と, 投与前
に脳症の見られなかった 3 例においては脳症の出現と 悪化，ないしその切迫を思わせる臨床症状である嘔気 と NCT の延長が認められた，今日本邦では肝不全患 者の血漿アミノグラムのインバランスを補正すること により脳症が改善するという Fischer の仮説 ${ }^{1,2)} に も$ とづいて, 急性及び慢性肝不全患者に BCAAに富ん だ特殊組成アミノ酸輸液が広く投与されている。一般 


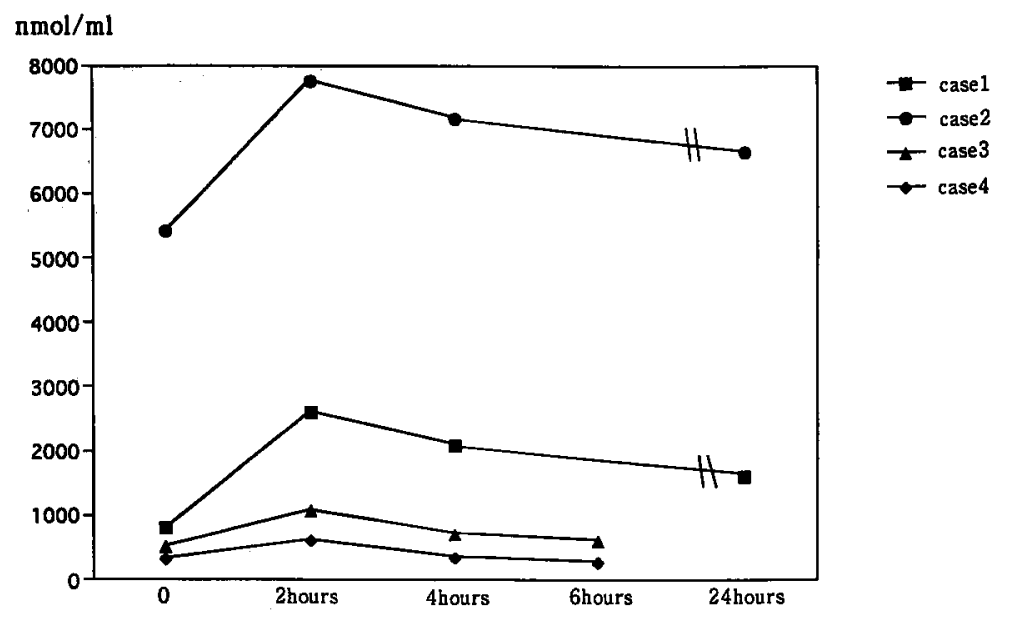

Fig. 6 Changes in plasma alanine levels before and after the administration of Fischer's solution.

にアミノ酸は生体内で代謝されるときに, アミノ窒素 の過剰な $\mathrm{N}$ は urea cycleにより尿素として除かれ， 残りの炭素骨格はクエン酸回路により $\mathrm{CO}_{2}$ へと分解 されるか,グルコースを作るか, ケトン体を生成する。 そして urea cycle 系の酵素は主として肝蔵の小葉の 中の zone 1, 2に存在しており ${ }^{11)}$ ，この領域にも広範な 壊死が及ぶ劇症肝炎では当然のことながら尿素の産生 能が低下する．この状況で urea cycle の尿素産生の capacity 以上にアミノ酸負荷がかかれば, アンモニア が血中に放出されることになる。 そして，このアンモ ニアは体内の他の $\mathrm{N}$ 処理機構である $\alpha$ ケトグルタル

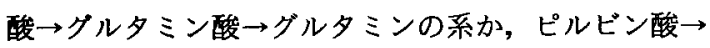
アラニンの系で処理されるが，この系は共に $\mathrm{N}$ 処理能 は高くないため, 体外から過大に $\mathrm{N}$ 負荷を行えば当然 血中にアンモニアが蓄積することになる．更に問題な ことは，一旦グルタミンやアラニンが生成されても， グルタミナーゼやトランスアミナーゼの作用により deamination を受けて, 再びアンモニアが放出される ことである. 今回の我々の検討では，4例全例で血中 アンモニア值の異常な上昇を示し, かつ, 症例 1 と 2 では異常高値のまま24時間以上持続した。

このことは, 症例 1,2 は症例 3,4 に比して投与 後の尿素の上昇が小さい事から明かなように, 上り重 篤な urea cycle 機能の低下が存在が想定される. 負荷 された BCAA は投与終了後より血中濃度が急速に低 下することから明かなように代謝されてアンモニアを 放出し，それが主として骨格筋でグルタミンやアラニ ンに変換され, グルタミンやアラニンから再度放出さ
れたアンモニアを urea cycle の障害により処理でき ない為に,高アンモニア血症が持続したと推察される. 急性肝不全に対する特殊組成アミノ酸投与については 無効という評価䦿なされていたものの, 高アンモニ ア血症を誘発して昏睡を覀化させるという報告は本報 告が初めてである.この理由は, これまでの血漿交換

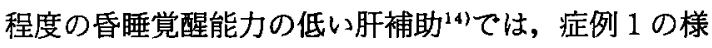
な重症症例では昏睡を覚醒させることができず, 特殊 組成アミノ酸の持つ昏睡誘発の可能性が明かにできな かったからと考えられる. また症例 3 と 4 のように症 例 1 と 2 に比して軽症の劇症肝炎や自然回復傾向をと る急性肝炎重症型においても特殊組成アミノ酸製剤の 投与により嘔気やNCT の悪化が見られたことより, この場合も脳症誘発の危険性が考えられる。

本報告は urea cycle 機能が障害されている急性肝 不全例では，たとえ BCAA の豊富なアミノ酸輸液の 形でも, 残存する $\mathrm{N}$ 処理機能を上回ってアミノ酸を投 与することは,アンモニアの上昇により脳症を悪化さ せる危険があるという臨床的観察である。我が国では 余りにも Fischer の仮説が深く浸透しているために, 今日までこの様な危険性が省みられなかったと思われ る.

\section{結 論}

urea cycle 機能の障害が想定される劇症肝炎及び急 性肝炎重症型においては，特殊組成アミノ酸製剤の投 与は脳症の増悪ないしは発現を誘発する危険性があ ク，その投与には慎重な注意が必要である。 


$$
\text { 文 献 }
$$

1) Fischer JE, Baldessarini RJ : False neurotransmitter and hepatic coma. Lancet 2 : 75-79, 1971

2) Fischer JE, Rosen HM, Ebied AM, et al : The effect of normalization of plasma amino acids on hepatic encephalopathy in man. Surgery 80 : 77-91, 1976

3) Rossi-Fanelli F, Riggio O, Cangiano C, et al : Branched chain amino acids versus lactulose in the treatment of hepatic coma. Dig Dis Sci 27 : $929-935,1982$

4) Wahren J, Denis J, Desurmont P, et al : Intravenous administration of branched chain amino acids effective in the treatment of hepatic encepalopathy. A multicenter study. Hepatology 3 : 475-480, 1983

5) Fiaccadori F, Ghinelli F, Pedretti G, et al : Branched chain enriched amino acid solution in the treatment of hepatic encephalopathy: A controlled trial. Ital J Gastroent $17: 5-10,1985$

6) Vistrup H, Gluud C, Hardt F, et al: Branched chain enriched amino acid versus glucose treatment of hepatic encephalopathy. J Hepatol 10 : $291-296,1990$

7）渡辺明治, 東 俊宏, 林 正作, 他：劇症肝炎の治 療における分枝鎖アミノ酸輸液の臨床的意義. 肝 臓 $20: 702-713,1979$

8）高橋善弥太, 清水 勝：急性肝不全における Fischer 液使用が生存率に及涩す影響. 肝臓 33 ：
200, 1992

9) Yoshiba M, Sekiyama K, Iwamura $Y$, et al: Development of reliable artificial liver support (ALS)-Plasma exchange in combination with hemodiafiltration using high-performance membranes. Dig Dis Sci 38: 469-476, 1993

10）井上和明, 与芝 真, 関山和彦, 他：特殊組成アミ ノ酸輸液の投与を契機として脳症が発現した亜急 性型劇症肝炎の 1 例. 第20回日本急性肝不全研究 会記録. 肝藏 36:255-256, 1995

11) Gumucico JJ, Chianale J : Liver cell heterogeneity and liver function. In: The Liver Biology and Pathobiology, Edited by Arias IM, Jakoby WB, Popper H, et al. Raven Press, New York, 1988, p931-947

12) Yoshiba $M$, Sekiyama $K$, Inoue $K$, et al : Interferon and cyclosporine $A$ in the treatment of fulminant viral hepatitis. J Gastroenterol $30: 67$ $-73,1995$

13) Murawaki $Y$, Tanimoto $K$, Hirayama $C$, et al : Simple anda rapid microdiffusion method for blood ammonia using a reflectance meter and a reagent plate, and its clinical evaluation for liver disease. Clin Chem Acta 144: 195-202, 1984

14）与芝 真, 三條健昌, 井上 昇, 他：急性肝不全に 対する血獎交換の効果と限界. 日消誌 $77: 1397$ $-1402,1980$ 


\title{
Deleterious effect of branched chain amino acid enriched solution in acute severe and fulminant hepatitis
}

\author{
Kazuaki INOUE, Makoto YosHIBA, Kazuhiko SEKIYAMA, \\ Ichiu $\mathrm{KOH}$ and Rikiya FUJITA*
}

It has been suggested by an annual surveillance study that the use of Fischer's branched chain enriched amino acid solution lowers the survival rate of patients with fulminant hepatic failure (FHF). In order to ascertain whether the Fischer's solution is deleterious in FHF, we assessed coma level and plasma levels of substances closely related to urea cycle functions before and after the infusion of the Fischer's solution in cases with FHF and acute severe hepatitis (ASH).

Three patients with FHF and a patient with ASH underwent two hour infusion of Fischer's solution, and changes in coma grade and plasma level of ammonia, urea, glutamine and alanine were sequentially monitored.

One patient with FHF fell into deep coma six hours after the end of the infusion. Two patients, one with FHF and one with ASH, showed nausea, vomiting and disturbance in conducting the number connection test. Remaining one was persistently in deep coma. Ammonia, glutamine and alanine were elevated after the start of the infusion, and sustained in high levels until 24 hours after the end of the infusion in the two coma patients.

These observations imply that infusion of Fischer's solution is deleterious in FHF because it can elevate plasma ammonia level and deteriorate hepatic coma.

* Division of Gastroenterology, Showa University Fujigaoka Hospital (Yokohama) 